\title{
Sharp van der Heijde Joint Space Narrowing Score
}

National Cancer Institute

\section{Source}

National Cancer Institute. Sharp van der Heijde Joint Space Narrowing Score. NCI

Thesaurus. Code C128989.

The numerical value that represents the result of a clinical assessment of joint space narrowing based on the Van der Heijde modification of the Sharp Joint Space Narrowing Assessment (Van der Heijde DM, van Riel PL, Nuver-Zwart IH, Gribnau FW, van de Putte LB. Effects of hydroxychloroquine and sulphasalazine on progression of joint damage in rheumatoid arthritis. Lancet 1989;1:1036-8). 